\title{
Improving the Learning Outcome of Passing Basic Motion by Using Side-Foot in the Football Game Through the Blocking Game Media
}

\author{
Tatang Iskandar \\ Islamic University 45 Bekasi \\ Bekasi, Indonesia \\ Papapt42nk@gmail.com
}

\begin{abstract}
This study aims to improve the learning outcome of passing basic motion by using the side-foot in the football games through blocking game media. In the first cycle of the research, the percentage of students who were able to complete the passing learning outcome reached $70 \%$ or 28 students. This percentage is an increase from the percentage of students' learning achievement at the initial observation stage which only reached $30 \%$ or 12 students. Then in the second cycle of the research, the increase in student passing learning outcome climbed significantly up to $80 \%$ of the number of grade IVA students in Lawanggintung 2 State Elementary School, Bogor City; in other words, 32 students have been able to achieve the predetermined minimum completeness criteria of 75 . Therefore, it can be concluded that through the blocking game media in football game, it has proven to be effective in improving the learning outcomes of passing, football, and blocking.
\end{abstract}

\section{Keywords: passing, football game, blocking game media}

\section{INTRODUCTION}

Physical Education is the process of education through activities arranged to improve physical fitness, develop motion skills, knowledge, and healthy living behaviors. The nature of physical education is an activity to train one's body, not only physically but also spiritually. To achieve the learning objectives in schools, cooperation and support are needed from the teachers, students, curriculum, infrastructure, environment and social conditions. In the implementation of physical education in elementary schools, the materials delivered should be in accordance with the existing curriculum.

From the curriculum in elementary school, there are various kinds of materials taught to students, one of which is football game. The Competency Standards of Physical Education in Elementary School for class IV semester 2 is practicing the basic techniques of passing in the football game and the values contained. This is then elaborated in Basic Competence which is practicing basic techniques of passing techniques in the football game, both individually and in team, with modified rule, teamwork value, sportsmanship and honesty.

In presenting passing material by using the side-foot in football game, the researcher still used the old techniques, namely the method of counting command or whistle. After a while, the researcher was aware of the old techniques in presenting the materials were less attractive to students to participate in learning. Students felt bored with the techniques which did not vary. Effective learning activities cannot arise by themselves, but teachers should be able to create optimal learning so that students can learn passing techniques in football game.

The researcher tried to use learning media which was more effective and efficient, namely the blocking game media with the expectation that students were more interested in participating in learning. Solving the students' boredom in learning passing material in football game will result in increased learning interest. The blocking game media is media which is in accordance with the current development (advances in science and technology), which includes media that can be seen and heard.

Of the common problems faced by Physical Education teachers in delivering materials, especially the passing basic motion in football game, the researcher is interested in conducting Classroom Action Research (CAR) on grade IV students of Lawanggintung 2 State Elementary School, Bogor City in the Academic Year of 2017/2018 with the title "Improving the Learning Outcome of Passing Basic Motion by Using Sidefoot in the Football Game through the Blocking Game Media on Class IV Students Of Lawanggintung 2 State Elementary School, Bogor City".

\section{A. Football Game}

Football, according to reference [1], is a team game played by two teams; each team consists of eleven players including a goalkeeper. The game may be done with all parts of the body except with both arms (hands). Most of the game is done with foot skills, except the goalkeeper who is free in playing the ball using any parts of their body, with their feet and hands according to the rules. The purpose of each team is to create a goal to the opponent's goal and defend their own goal in order to prevent the opponent team to create goals. Based on the opinions of the experts, it can be concluded that the football game is a team game played by eleven people with the aim of putting the ball into the opponent's goal as much as possible and preventing the opponent team to create goals.

In the basic skills of playing football, a supporting element is needed. Reference [3] argues that there are two supporting elements in playing football skills, namely players' physical and football playing techniques. One of the techniques in football game is passing by using the sidefoot.

According to reference [4], kicking the ball with the sidefoot can be preceded by standing facing the movement, putting the resting foot beside the ball with the knee bent slightly and the shoulder facing the movement. The two 
Based on the table above, the initial observations show hands are next to the body slightly on the back, ankles used for kicking are turned out, and the view is centered on the ball. Then, the player pulls the foot that will be used to kick back then swings forward towards the ball, applies the foot on the ball right in the middle of the ball, and moves the body weight forward following the direction of movement.

\section{B. Blocking Game Media}

Reference [5] argues that the use of learning media in the teaching and learning process can arouse new interests, generate motivation and stimulation of learning activities, and even bring psychological influences on students. In this study, the media used was the blocking game. Blocking game media is an activity for pleasure, whether by using a tool or not, so that it builds conditions which can make students able to gain knowledge, skills, or attitudes. According to reference [6], blocking is a traditional sport game which does not use any tools as other traditional games. Blocking traditional sport is played in teams, both male and female. The number of team members is 8 people, consisting of 5 people as core players and the remaining 3 people as the reverse players.

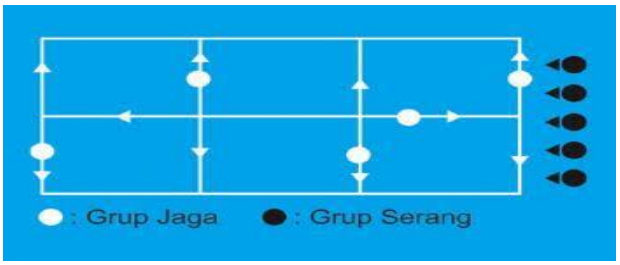

Fig. 1. Blocking Game Media [6]

\section{METHOD}

The method used in this study is the Classroom Action Research method. Reference [7] states that classroom action research (CAR) is research initiated to solve problems in teaching and learning in class directly. Reference [8] asserts that classroom action research is a study which is oriented to the application of action with the aim of improving quality or problem solving in a group of people studied and observing the level of success or consequence of their actions, to then be given further actions that are refinement of actions or adjustments to conditions and the situation so that better results are obtained. Based on the needs, the research subjects chosen by the researcher were students in class IVA Lawanggintung 2 State Elementary School, Bogor City, with the total of 40 students, consisting of 26 males and 14 females. The duration of the study was four weeks or 2 cycles with 1 cycle of 2 meetings. The research site was in Lawanggintung 2 State Elementary School, Jl. Lawanggintung No. 38, Bogor City. The test instrument used was a cognitive, affective and psychomotor assessment with a Minimum Completion Criteria of 75 .

\section{RESULTS AND DISCUSSION}

TABLE I. PASSING LEARNING OUTCOME OF THE INITIAL OBSERVATION STAGE

\begin{tabular}{|l|l|l|l|l|}
\hline Assessment Aspects & Complete & $\begin{array}{c}\text { Not } \\
\text { Complete }\end{array}$ & $\begin{array}{c}\text { Max } \\
\text { Score }\end{array}$ & $\begin{array}{c}\text { Min } \\
\text { Score }\end{array}$ \\
\hline $\begin{array}{l}\text { Affective } \\
\text { Cognitive } \\
\text { Psychomotoric }\end{array}$ & $12(30 \%)$ & $28(70 \%)$ & 75 & 25 \\
\hline
\end{tabular}
that students who meet the Minimum Completion Criteria are only 12 students or $30 \%$, while students who have not completed since the grades are below the Minimum Completion Criteria are 28 students or $70 \%$.

In the first cycle of research on the passing learning outcome in the football game through blocking game media for students in class IVA Lawanggintung 2 State Elementary School Bogor City, the researcher conducted research through four stages, namely, planning, acting, observing, and reflecting. After carrying out and completing the first cycle, the researcher, together with fellow teachers who act as collaborators, conducted observations, discussions and reflections in order to obtain an overview of student learning outcomes regarding the material being taught.

Based on the data in table 2, the first cycle shows students who meet the minimum completion criteria of 28 students or $70 \%$, while students who have not completed since the grades are below minimum completion criteria are 12 students or $30 \%$. An increase in the number of students who have completed has not met the researcher's target which is $75 \%$ of students. Therefore, there is the second cycle of action, that is, students were asked to follow the passing learning in football game through the blocking game learning media more seriously and to pay attention to the explanations and demonstrations. Therefore, the focus is on conducting observations so that they can master and understand the class well, so that the quality of learning outcomes can be achieved optimally.

Based on the data in Table 3, the second cycle shows students who meet the minimum completion criteria totaling 32 students or $80 \%$, while students who have not completed since the grades are below the minimum completion criteria are 8 students or $20 \%$. This shows the researcher's target which is $75 \%$ of the students has been reached or exceeded, so that the researcher does not need to conduct further research.

TABLE II. PASSING LEARNING OUTCOME BY USING THE SIDEFOOT IN THE FIRST CYCLE

\begin{tabular}{|l|l|l|l|l|}
\hline \multicolumn{1}{|c|}{$\begin{array}{c}\text { Assessment } \\
\text { Aspects }\end{array}$} & Complete & $\begin{array}{c}\text { Not } \\
\text { Complete }\end{array}$ & $\begin{array}{c}\text { Max } \\
\text { Score }\end{array}$ & $\begin{array}{c}\text { Min } \\
\text { Score }\end{array}$ \\
\hline $\begin{array}{l}\text { Affective } \\
\begin{array}{l}\text { Cognitive } \\
\text { Psychomotor }\end{array}\end{array}$ & $28(70 \%)$ & $12(30 \%)$ & 92 & 50 \\
\hline
\end{tabular}

TABLE III. PASSING LEARNING OUTCOME OF THE SECOND CYCLE

\begin{tabular}{|c|c|c|c|c|}
\hline $\begin{array}{c}\text { Assessment } \\
\text { Aspects }\end{array}$ & Complete & $\begin{array}{c}\text { Not } \\
\text { Complete }\end{array}$ & Max Score & $\begin{array}{c}\text { Min } \\
\text { Score }\end{array}$ \\
\hline $\begin{array}{c}\text { Affective } \\
\text { Cognitive } \\
\text { Psychomotor }\end{array}$ & $32(80 \%)$ & $8(20 \%)$ & 100 & 50 \\
\hline
\end{tabular}

In the first cycle, learning ran well and smoothly, students were also enthusiastic, but the use of learning media used in learning has was not able to be utilized and mastered optimally by students, so that the first cycle learning was less effective and had not yet reached optimum results. The student learning outcome in the second cycle improved since students had a better understanding of the material being taught and the learning media could be utilized and mastered 
Lawanggintung 2 State Elementary School, Bogor City, the following conclusions are obtained: with a minimum completion criteria of 75 , at the initial observation, the number of students who completed is 12 students or $30 \%$, while those who have not completed are 28 students or $70 \%$ with the highest score of 75 and the lowest score of 25 . In the first cycle, the number of students who have completed is $70 \%$ or 28 students and who have not completed are 12 students or $30 \%$ with the highest score of 92 and the lowest score of 50. Meanwhile, in the second cycle the number of students who completed is 32 students or $80 \%$ and 8 students or $20 \%$ have not completed with the highest score of 100 and the lowest score of 50 .

\section{REFERENCES}

[1] K. Anam, "Pengembangan Latihan Ketepatan Tendangan dalam Sepakbola untuk Anak Kelompok Umur 13-14 Tahun" Jurnal Media Ilmu Keolahragaan Indonesia, Vol. 3, Nomor 2, Edisi Desember 2013.

[2] P. E. Hartomo and E. Widyastuti, Buku Pegangan Guru Seri Permainan Bola Besar, Semarang: Aneka Ilmu, 2010.

[3] I. Hasanah, Sepakbola, Bandung: PT. Indahjaya Adipratama, 2012.

[4] A. Rohim, Bermain Sepakbola, Semarang : CV. Aneka Ilmu, 2008.

[5] O. Hamalik, Kurukulum dan Pembelajaran, Jakarta: Bumi Aksara, 2009.

[6] B. Laksono, Kumpulan Permainan Rakyat Olahraga Tradisional, Jakarta: Kementrian Pemuda dan Olahraga Republik Indonesia, 2012.

[7] M. Kusumawati, Penelitian Pendidikan, Bekasi: Percetakan ST, 2014.

[8] T. Trianto, Panduan Lengkap Penelitian Tindakan Kelas (Classroom Action Research), Jakarta: Prestasi Pustaka raya, 2012.

Based on the results of research, the analysis of data and facts during the research process in class IVA 